\title{
Catalytic Pyrolysis of Biomass to Synthesize Bio-oil and Chemicals: A Review
}

\author{
Nugroho Dewayanto ${ }^{1, *}$, Mohd Ridzuan Nordin ${ }^{2}$ \\ ${ }^{1}$ Section of Chemical Process Technology, Universiti Kuala Lumpur - Malaysian Institute of Chemical and \\ Bioengineering Technology, 1988 Vendor City, 78000 Alor Gajah, Melaka, Malaysia \\ ${ }^{2}$ Faculty of Technology Management and Technopreneurship, Universiti Teknikal Malaysia Melaka, Hang \\ Tuah Jaya, 76100 Durian Tunggal, Melaka, Malaysia \\ *email: nugroho@unikl.edu.my
}

\begin{abstract}
Increasing of global energy demand and depletion of fossil fuels reserves encourage people to search alternative energy resources. Biomass becomes promising candidate as alternative energy sources since their sustainability. Pyrolysis is one of method to convert biomass into bio-fuel. Almost all of biomass materials can be converted into products by pyrolysis process. However, quality of bio-oil produced by pyrolysis is still considered as low quality, due to their high oxygen content and acidity. This paper provides a critical review of catalytic pyrolysis of biomass to produce bio-oil with better properties. Types of catalysts are discussed in this manuscript, as well as their capability to reduce the oxygen content of product and enhance the properties of bio-oils.
\end{abstract}

Keywords: bio-oil, biomass, catalytic pyrolysis, alternative energy

\section{Introduction}

Conversion of biomass into energy sources has been practiced from long time ago. Direct combustion of biomass, historically, has been the primary source of energy throughout the world, particularly for residential activity and small industry in the rural area. Unfortunately, direct burning of loose biomass in conventional grate is always associated with low energy efficiency and contributes adverse impact to the environment, particularly the air quality. Modern technology which offers clean and efficient energy conversion is required to improve the attractiveness of biomass utilization as energy sources. Many techniques have been developed to transform biomass into energy. Hernandez [1] classified the conversion process into two categories biochemical and thermochemical. Biochemical usually consists of two processes: gasification or hydrolysis followed by fermentation to form ethanol. Thermochemical processes required relatively high temperature and sometimes high pressure to decompose biomass into the smaller molecular weight compound that can be converted into hydrocarbons, alcohols or aromatics via the catalytic process.

There are two main pathways in the thermochemical process of biomass conversion: pyrolysis and gasification. Pyrolysis is thermal decomposition of biomass in the absence of oxygen. Main products of pyrolysis are bio-oil or pyrolytic liquid, solid char and gas. Bio-oil produced from biomass contains high oxygenated compounds. This causes problem of the instability of the oil during storage, where viscosity, calorific value, and density all are affected. Therefore, utilization of the oil requires a general decrease in the oxygen content in order to separate the organic product from the water, increase the heating value, and increase the stability [2]. Hydrodeoxygenation, a catalytic reaction between bio-oil and hydrogen becomes the most common bio-oil upgrading process. In this process, oxygen is eliminated from bio-oil as water. Otherwise, the bio-oil can be upgraded by hydrocracking, where the chemical compounds in the bio-oil were cracked into smaller molecules. Feasibility of co-processing of bio-oil upgrading in a Fluid Catalytic Cracking (FCC) facilities of crude oil refinery were also investigated [3]-[5]. Instead of catalytic upgrading of bio-oil, the addition of catalyst during the pyrolysis process was proposed as the alternative pathway to enhance the biooil properties. The direct use of catalysts could decrease the pyrolysis temperature, increase the conversion of biomass and the yield of bio-oil, and change the distribution of the pyrolytic liquid products then improve the quality of the bio-oil obtained [5]-[8]. 


\section{Catalyst}

Several types of catalyst were employed in pyrolysis of biomass to produce fuels or chemicals. Zeolitebased catalysts are the most often used catalyst in pyrolysis, instead of metal oxides, inorganic carbonates, and other organosilicate materials. Table 1 shows catalysts used in bio-oil production for selected biomass feedstock, either in single or dual stage reaction. Catalyst selection is based on the main purpose of the pyrolysis process. Besides the ability of the catalyst to lower the activation energy of the whole process, the selectivity of the catalyst is also important. Zeolitics materials are usually employed to obtain smaller hydrocarbon molecules since the structure of zeolite able to facilitate thermal cracking of large molecules. In order to maximize gas production from biomass pyrolysis, metal oxides, such as calcium oxide and magnesium oxide, may be used as the catalyst [9].

Table 1. Catalyst and biomass feedstock used in catalytic pyrolysis

\begin{tabular}{|c|c|c|c|}
\hline Catalyst & Feedstock & Reactor type & Reference \\
\hline \multirow[t]{11}{*}{ ZSM-5 } & Rice husk & Fixed bed & {$[8]$} \\
\hline & Pine sawdust & Fluidised bed & {$[7],[10]$} \\
\hline & Pine wood chip & Fixed bed & [11] \\
\hline & Pine barks & Fixed bed & {$[12]$} \\
\hline & Aspen wood & Tubular bed & {$[13]$} \\
\hline & Sawdust & Fluidised bed & [14] \\
\hline & $\mathrm{EFB}$ & Fixed bed & {$[15]$} \\
\hline & Nannochloropsis sp. & Fixed bed & [16] \\
\hline & Beech wood & Fixed bed & {$[5]$} \\
\hline & Corn stalks & Fixed bed & [17] \\
\hline & Corncob & Fluidised bed & [18] \\
\hline \multirow[t]{2}{*}{ H-beta-zeolite } & Pine sawdust & Fluidised bed & [10] \\
\hline & Oak & Packed bed & [19] \\
\hline \multirow[t]{2}{*}{ Mordenite } & Pine sawdust & Fluidised bed & {$[10]$} \\
\hline & Oak & Packed bed & [19] \\
\hline $\mathrm{FeO}$ & Sawdust & Fixed bed & [20] \\
\hline \multirow[t]{5}{*}{$\mathrm{Al}_{2} \mathrm{O}_{3}$} & Sawdust & Fixed bed & [20] \\
\hline & Olive bagasse & Fixed bed & [21] \\
\hline & Hazelnut bagasse & Fixed bed & [21] \\
\hline & Beech wood & Fixed bed & {$[5]$} \\
\hline & Miscanthus giganteus & Fixed bed & [22] \\
\hline \multirow[t]{2}{*}{$\mathrm{CaO}$} & Sawdust & Fixed bed & [20] \\
\hline & Sewage sludge & Fluidised bed & {$[23]$} \\
\hline $\mathrm{MnO}$ & Sawdust & Fixed bed & [20] \\
\hline $\mathrm{CuO}$ & Sawdust & Fixed bed & [20] \\
\hline $\mathrm{Cr} 2 \mathrm{O} 3$ & Sawdust & Fixed bed & [20] \\
\hline $\mathrm{La} 2 \mathrm{O} 3$ & Sewage sludge & Fluidised bed & {$[23]$} \\
\hline $\mathrm{B} 2 \mathrm{O} 3$ & $\mathrm{EFB}$ & Fixed bed & [24] \\
\hline $\mathrm{ZnO}$ & Rice husk & Fixed bed & {$[25]$} \\
\hline $\mathrm{ZnO}$ & Pine sawdust & Fluidised bed & [26] \\
\hline Sodium feldspar & Olive, hazelnut bagasse & Fixed bed & {$[21]$} \\
\hline Al-MSU-F & Rice husk & Fixed bed & {$[8]$} \\
\hline Al-MCM-41 & Rice husk & Fixed bed & [8] \\
\hline Rice husk ash & Rice husk & Fixed bed & [8] \\
\hline $\mathrm{Na} 2 \mathrm{CO} 3$ & Microalgae & Fixed bed & [27] \\
\hline \multirow[t]{2}{*}{$\mathrm{K} 2 \mathrm{CO} 3$} & Reed & Fixed bed & [28] \\
\hline & Cellulose & Fixed bed & [29] \\
\hline
\end{tabular}

Generally, the presence of zeolitic materials in biomass pyrolysis affects the product distribution. Aho et al. investigated the effect of different type of zeolites in product distribution of biomass pyrolysis [10]. As shown in Figure 1, bio-oil yield decreases for all type of zeolites, while aqueous product increases compared to that of non-catalytic pyrolysis. It is likely that the elimination of oxygen occurred through the formation of water molecules. Increase of solid product might be caused by coke formation during high-temperature thermal 
treatment. In this study, gas production was relatively uniform and is not affected by types of zeolite. However, some studies indicated the increase of gaseous product due to cracking reaction during thermal treatment of biomass [5], [12], [17], [19], [30].

In the pyrolysis process, zeolite facilitates conversion of oxygenates compounds into aromatics hydrocarbons. Figure 2 illustrates the oxygenated compound present in the bio-oil and aromatics resulted from catalytic pyrolysis on zeolites. According to Bridgwater, aromatisation is an important step in the reactions of hydrocarbons over zeolite catalysts [31]. It is in agreement with some previous studies in catalytic pyrolysis of biomass by using zeolite, which indicated the increase of aromatic hydrocarbon content in bio-oil compared to that of non-catalytic pyrolysis. Application of ZSM-5 on pyrolysis of microalgae increased the content of aromatic carbon almost three-fold, from 19.8 to 50.8\% [32]. Wang et al. found that ZSM-5 catalyst increased the aromatic hydrocarbon content from $0.72 \%$, obtained by non-catalytic pyrolysis of Douglas-fir, to $6.89 \%$ [33]. Moreover, increasing of aromatic hydrocarbon by about 50\% from non-catalytic pyrolysis was achieved in rice husk pyrolysis by using ZSM-5 as catalyst [8] Aromatisation reaction may be preceded by the DielsAlder reaction, in which cyclic and aromatic compounds are produced by cracking combine with each other as shown in Equation 1 [34]. C-C bonds cracking are promoted by strong acidity and shape selectivity of ZSM5. It also determines the shorter chain length of products [35].
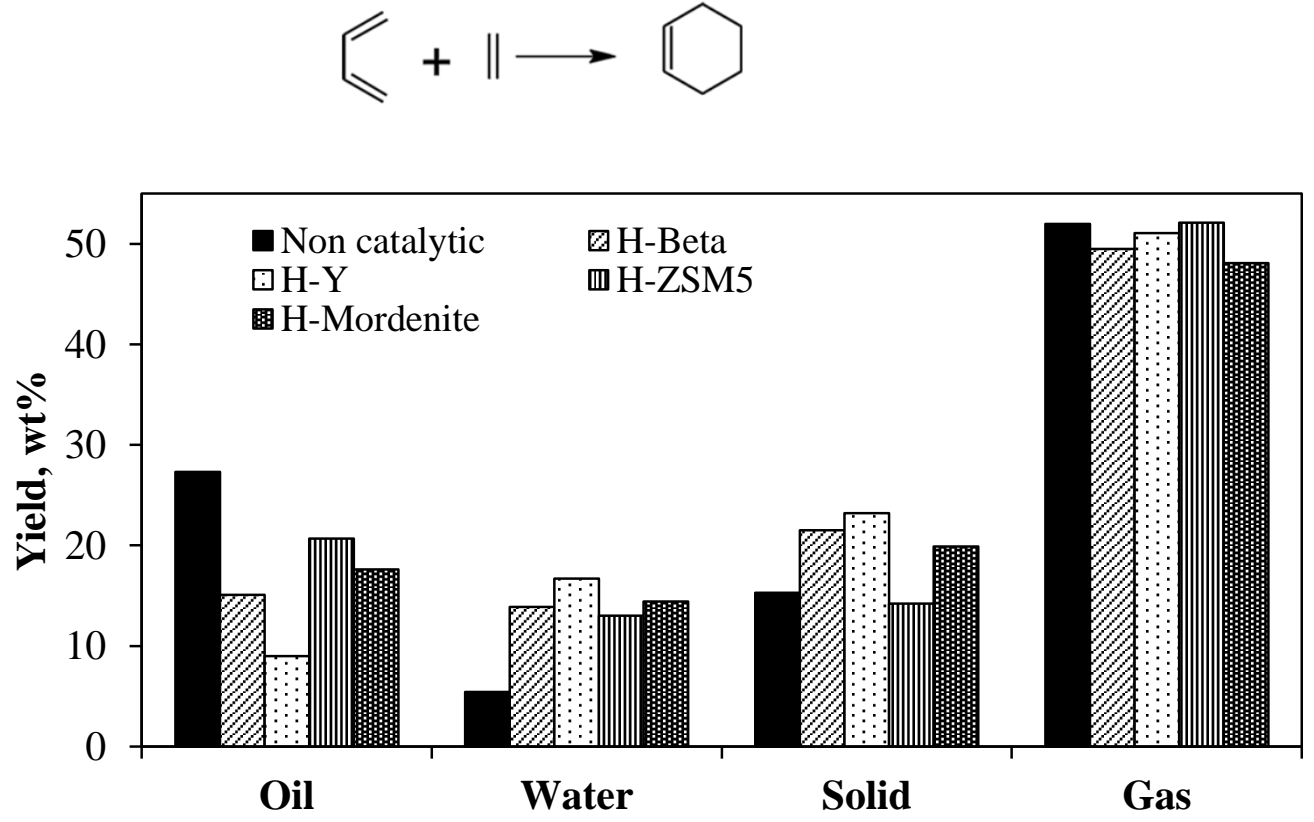

Figure 1. Product distribution of catalytic pyrolysis of pine chips using different zeolite-based catalyst [10]

The deoxygenation of biomass also occurs through reaction of decarbonylation and decarboxylation reaction [36]. Reduction of oxygen content from 33 to $13 \%$ was reported in catalytic pyrolysis using ZSM-5 as the catalyst. The oxygen contained in the feedstock are removed as $\mathrm{CO}, \mathrm{CO}_{2}$ and $\mathrm{H}_{2} \mathrm{O}$ [37] . At lower temperature, oxygen removal is in the form of $\mathrm{H}_{2} \mathrm{O}$, while at higher temperatures, it was as $\mathrm{CO}$ and $\mathrm{CO}_{2}$ [38], [39]. Modification of ZSM-5 used as biomass pyrolysis catalysts was attempted to enhance the oxygen rejection. It may be obtained by producing more carbon oxides and less water, thus provide more hydrogen available to be incorporated into hydrocarbon [36]. Moreover, zeolites also effectively increases the $\mathrm{C} / \mathrm{O}$ ratio and improves the octane number [40], [41]. The presence of transition metal promoted zeolitic materials lead to the production of more hydrocarbons and less coke than that of commercial ZSM-5 catalyst's usage [13]. Thus, some transition metals modified catalysts were employed in pyrolysis to enhance the bio-oil characteristic, such as CeZSM-5, CoZSM-5, CoHZSM-5, GaZSM-5, and NiZSM-5.

Calcium oxide $(\mathrm{CaO})$ is widely known as a potential catalyst for biomass gasification to produce hydrogen and syn-gas. Impregnation of $\mathrm{CaO}$ with sawdust successfully increased the rate of hydrogen production in the temperature-programmed gasification [42]. Increase of $\mathrm{H}_{2}$ yields were also observed in gasification of pine bark [43], pine sawdust [44], the empty palm fruit bunch [45]. Critical review on application of $\mathrm{CaO}$ as a catalyst of biomass gasification was also conducted by Udomsirichakorn \& Salam [46]. Nevertheless, CaO was also employed as a catalyst in pyrolysis of biomass to produce bio-oil. In the catalytic pyrolysis of white 
pine biomass using $\mathrm{CaO}$, [47] reported that the oxygen content in the bio-oil obtained and the contents of formic and acetic acids were lower than those in the bio-oil obtained by pyrolysis of the same biomass material. Presence of $\mathrm{CaO}$ in sewage sludge pyrolysis slightly reduced the bio-oil yield from 43 to $39-40 \mathrm{wt} \%$ due to the catalytic cracking of pyrolysis vapor. However, the chlorine content was effectively reduced from 498 to $73 \mathrm{ppm}[23]$.

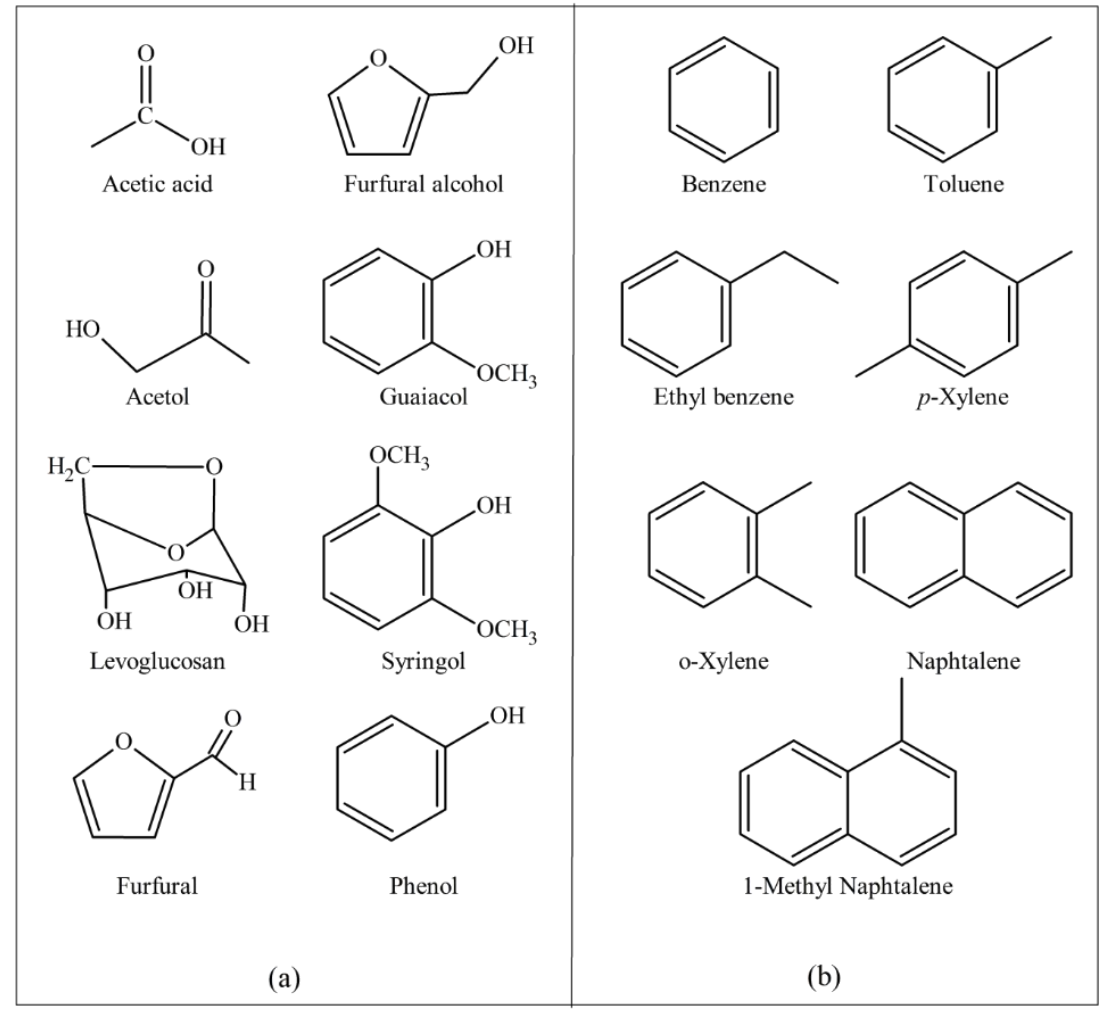

Figure 2. Typical oxygenated compounds associated with fast pyrolysis of biomass (a), and aromatic hydrocarbons produced by catalytic pyrolysis using zeolites (b) [41]

The performance of some other metal oxides as catalyst on catalytic pyrolysis was also studied, either for gasification or bio-oil production purposes. Table 2 summarizes the utilisation of metal oxide as a catalyst for selected biomass pyrolysis. Generally, gaseous product increases while liquid fraction decreases in the presence of metal oxide catalyst. Kuan et al. investigated the pyrolysis of sugarcane bagasse over $\mathrm{NiO}, \mathrm{CuO}, \mathrm{MgO}$ and $\mathrm{CaO}$ catalyst [48]. By using microwave heating, gaseous product increased from $58 \%$ in non-catalytic pyrolysis to 62 and $65 \%$ by addition of $\mathrm{CaO}$ and $\mathrm{MgO}$, respectively. At the same time, liquid yield of pyrolysis decreased from $23 \%$ to $19 \%$ by addition of $\mathrm{MgO}$. Addition of $\mathrm{CaO}, \mathrm{NiO}$ and $\mathrm{CuO}$ enhanced the liquid fraction to 24, 32, and $33 \%$, respectively.

The chemical composition of bio-oils is affected by the application of catalyst. This is because several types of chemical reaction are enhanced by catalyst such as cracking, carbonylation, carboxylation, dehydration, esterification, and isomerisation. Smets et al. (2013) compared the composition of bio-oil derived from rapeseed cake by using $\gamma-\mathrm{Al}_{2} \mathrm{O}_{3}, \mathrm{H}-\mathrm{ZSM} 5$ and $\mathrm{Na}_{2} \mathrm{CO}_{3}$ as catalyst. As shown in Figure 3, H-ZSM5 increased the portion of aromatic hydrocarbon and nitriles in bio-oil produced, but decreased the fraction of carboxylic acid, phenol and esters. $\gamma-\mathrm{Al}_{2} \mathrm{O}_{3}$ gave slight effect on reducing the phenolic compounds and aromatics, while $\mathrm{Na}_{2} \mathrm{CO}_{3}$ perfectly reduced the presence of carboxylic acid from more than $40 \%$ to less than $10 \%$. The presence of $\mathrm{B}_{2} \mathrm{O}_{3}$ as a catalyst reduced the content of methoxy-phenolic group in pyrolysis of empty palm fruit bunch and oil palm frond, from $16 \%$ to $12 \%$ and from $24 \%$ to $10 \%$, respectively. Methoxy-phenolic compounds could be formed at temperature below $400{ }^{\circ} \mathrm{C}$ due to the decomposition of holocellulose and lignin structure [24]. 
Table 2. Comparison of bio-oil yield between non-catalytic and catalytic pyrolysis using $\mathrm{CaO}$ and other metal oxides for various biomass feedstock type.

\begin{tabular}{lllll}
\hline Catalyst & Feedstock & $\begin{array}{l}\text { Bio-oil yield, wt\% } \\
\text { Non-catalytic }\end{array}$ & Catalytic & Reference \\
\hline$\gamma-\mathrm{Al}_{2} \mathrm{O}_{3}$ & Rapeseed cake & 47.1 & 40.8 & {$[49]$} \\
$\mathrm{CaO}$ & White pine powder & 39.4 & 34.1 & {$[47]$} \\
& Sewage sludge & 43.0 & $39.0-40.0$ & {$[23]$} \\
& Sugarcane bagasse & 23.0 & 24.0 & {$[48]$} \\
& Pine sawdust & 47.0 & 13.0 & {$[7]$} \\
$\mathrm{CuO}$ & Sugarcane bagasse & 23.0 & 34.0 & {$[48]$} \\
& Pine sawdust & 47.0 & 49.0 & {$[7]$} \\
$\mathrm{La}_{2} \mathrm{O}_{3}$ & Sewage sludge & 43.0 & $39.0-40.0$ & {$[23]$} \\
$\mathrm{MgO}$ & Sugarcane bagasse & 23.0 & 18.0 & {$[48]$} \\
& Pine sawdust & 44.0 & 16.0 & {$[7]$} \\
$\mathrm{NiO}^{\mathrm{SiO}}$ & Sugarcane bagasse & 23.0 & 32.0 & {$[48]$} \\
$\mathrm{SnO}$ & Pine sawdust & 47.0 & 19.0 & {$[7]$} \\
$\mathrm{ZnO}$ & Pine sawdust & 47.0 & 32.0 & {$[7]$} \\
\hline
\end{tabular}

Acidity of the catalyst has influenced the pyrolysis products. Aho et al. reported the effect of catalyst acidity on pyrolysis of pine wood chips [50]. The acidity of zeolites slightly influenced the formation of different groups of compounds. Decreasing of aldehydes formation was observed with an increasing acidity of the zeolites. Less ketones and phenols were formed in pyrolysis of pine biomass with acidic zeolites as bed material than with quartz sand in the bed. However, the presence of acidic catalyst did not significantly influence the amounts of acids and alcohols formed during the pyrolysis of biomass. Interestingly PAHs were obtained only when zeolites are used. Acid catalysed reactions such as cracking, dimerization, cyclization and dehydrocyclization takes place on Brønsted acid sites [50].

\section{Properties of bio-oil derived from catalytic pyrolysis}

The presence of catalyst affects the chemical composition of bio-oil obtained through the pyrolysis process. In general, bio-oil produced by catalytic pyrolysis has higher content of aromatic hydrocarbon and lower oxygen content. In addition, heavy molecules are cracked to form new compounds with smaller molecular weight. Moreover, the chemical composition of bio-oil greatly influences the physicochemical properties of bio-oil. Therefore, catalytic pyrolysis of biomass could enhance bio-oil properties such as oxygen content, moisture content, heating value, viscosity and density of bio-oils. Table 3 compares certain properties of biooil produced by non-catalytic and catalytic pyrolysis. Except for catalytic pyrolysis of pine sawdust over $\mathrm{ZnO}$, generally the presence of the catalyst reduced the oxygen content in bio-oil. As the result, calorific value of bio-oil also increased, since the lower oxygen content gave the lower calorific value according to the correlation proposed by Channiwala \& Parikh [51].

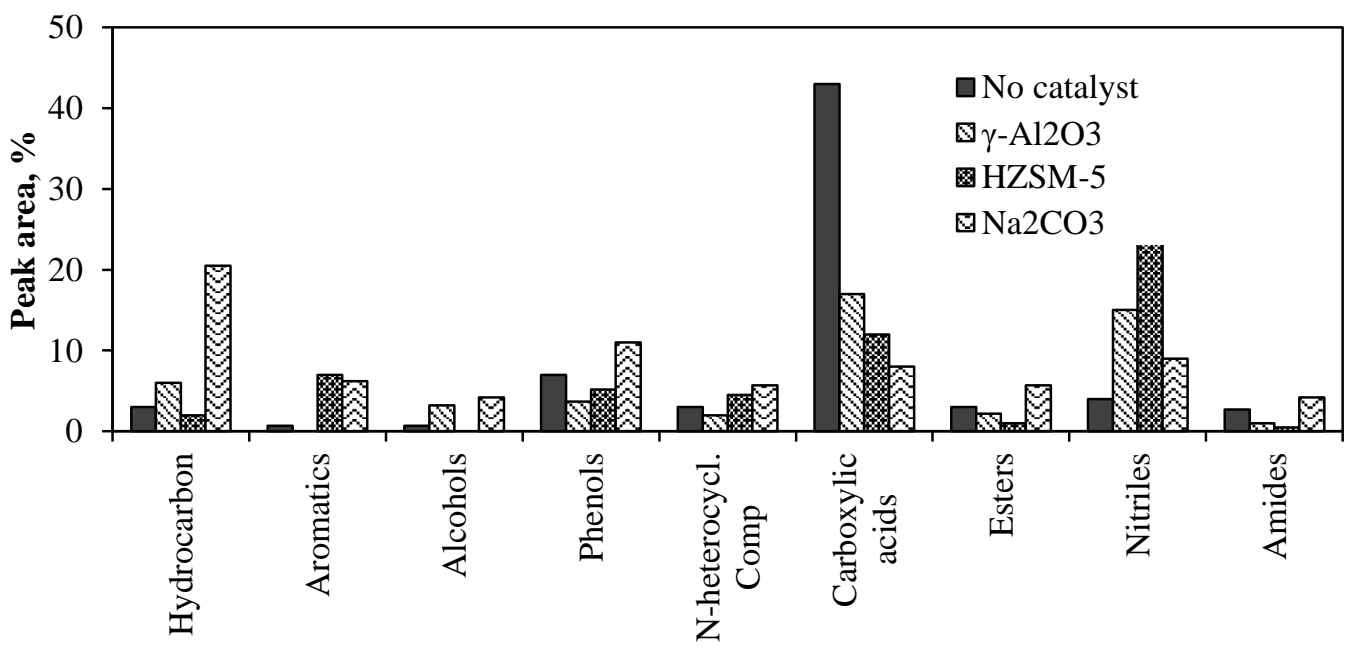

Figure 3. The distribution of different classes of compounds present in the oil fractions of the pyrolysis liquids derived from rapeseed cake by various catalysts [49] 
Besides the chemical composition, elemental composition and calorific value, some properties also become important since they can describe the character of the oil obtained by catalytic pyrolysis compared to that of conventional fuels such as gasoline, diesel oil and heavy oil. Good biofuel should have neutral $\mathrm{pH}$ to avoid the corrosion problems when the fuel is applied into the internal combustion engine. Fan et al. reported the significant increase in the $\mathrm{pH}$ of rape straw bio-oil from 2.30 to 5.15 by using H-ZSM5 as a catalyst [52]. Similar result was also reported for corncob catalytic pyrolysis. By using H-ZSM5, increase of $\mathrm{pH}$ from 2.8 (without catalyst) to 5.2 (with catalyst) was achieved [18]. Reduction of acid, ester and alcohol content may contribute to the increase of $\mathrm{pH}$ value of bio-oil. The presence of catalyst also enhances the stability of biooils. Nokkosmaki et al. studied the stability of bio-oil by artificial aging at $80{ }^{0} \mathrm{C}$ for $24 \mathrm{~h}$ [26]. Kinematic viscosity measurement showed that bio-oil produced by catalytic pyrolysis had better stability. The change by about 55\% (from 6 to $9 \mathrm{cSt}$ ), compared to $129 \%$ from 9 to $22 \mathrm{cSt}$ for bio-oil produced by non-catalytic pyrolysis.

Table 3. Comparison of oxygen content and HHV of bio-oil obtained by non-catalytic and catalytic pyrolysis

\begin{tabular}{|c|c|c|c|c|c|}
\hline Feedstock & Catalyst & Properties & Non-catal. & Catalytic & $\operatorname{Ref}(s)$ \\
\hline \multirow[t]{4}{*}{ Rape straw } & \multirow[t]{4}{*}{ H-ZSM5 } & $\mathrm{O}, \mathrm{wt} \%$ & 49.75 & 19.07 & \multirow[t]{4}{*}{ [53] } \\
\hline & & $\mathrm{O} / \mathrm{C}$ & 0.335 & 0.195 & \\
\hline & & $\mathrm{H} / \mathrm{C}$ & 1.426 & 1.510 & \\
\hline & & $\mathrm{HHV}, \mathrm{MJ} / \mathrm{kg}$ & 18.30 & 33.80 & \\
\hline \multirow[t]{4}{*}{ Corncob } & \multirow[t]{4}{*}{ H-ZSM5 } & $\mathrm{O}, \mathrm{wt} \%$ & 40.28 & 14.69 & \multirow[t]{4}{*}[18]{} \\
\hline & & $\mathrm{O} / \mathrm{C}$ & 0.58 & 0.15 & \\
\hline & & $\mathrm{H} / \mathrm{C}$ & 1.61 & 1.51 & \\
\hline & & $\mathrm{HHV}, \mathrm{MJ} / \mathrm{kg}$ & 18.80 & 34.60 & \\
\hline \multirow{4}{*}{$\begin{array}{l}\text { Nannochlor- } \\
\text { opsis sp. }\end{array}$} & \multirow[t]{4}{*}{ H-ZSM5 } & $\mathrm{O}, \mathrm{wt} \%$ & 30.09 & 19.53 & \multirow[t]{4}{*}{ [16] } \\
\hline & & $\mathrm{O} / \mathrm{C}$ & 0.40 & 0.22 & \\
\hline & & $\mathrm{H} / \mathrm{C}$ & 1.63 & 1.89 & \\
\hline & & $\mathrm{HHV}, \mathrm{MJ} / \mathrm{kg}$ & 24.40 & 32.20 & \\
\hline \multirow[t]{4}{*}{ Pine wood } & \multirow[t]{4}{*}{ H-Beta-25 } & $\mathrm{O}, \mathrm{wt} \%$ & 41.30 & 32.20 & \multirow[t]{4}{*}[6]{} \\
\hline & & $\mathrm{O} / \mathrm{C}$ & 0.62 & 0.42 & \\
\hline & & $\mathrm{H} / \mathrm{C}$ & 1.90 & 1.99 & \\
\hline & & $\mathrm{HHV}, \mathrm{MJ} / \mathrm{kg}$ & 30.96 & $\mathrm{n} / \mathrm{a}$ & \\
\hline \multirow{4}{*}{$\begin{array}{l}\text { Cottonseed } \\
\text { cake }\end{array}$} & \multirow{4}{*}{$\begin{array}{l}\text { Natural } \\
\text { zeolite }\end{array}$} & $\mathrm{O}, \mathrm{wt} \%$ & 19.90 & 14.33 & \multirow[t]{4}{*}[54]{,$[55]$} \\
\hline & & $\mathrm{O} / \mathrm{C}$ & 0.23 & 0.16 & \\
\hline & & $\mathrm{H} / \mathrm{C}$ & 1.54 & 1.52 & \\
\hline & & $\mathrm{HHV}, \mathrm{MJ} / \mathrm{kg}$ & 30.96 & $\mathrm{n} / \mathrm{a}$ & \\
\hline \multirow[t]{4}{*}{ Pine sawdust } & \multirow[t]{4}{*}{$\mathrm{ZnO}$} & $\mathrm{O}, \mathrm{wt} \%$ & 48.00 & 51.00 & \multirow[t]{4}{*}[26]{} \\
\hline & & $\mathrm{O} / \mathrm{C}$ & 0.82 & 0.91 & \\
\hline & & $\mathrm{H} / \mathrm{C}$ & 1.91 & 2.29 & \\
\hline & & $\mathrm{HHV}, \mathrm{MJ} / \mathrm{kg}$ & 18.00 & 18.00 & \\
\hline \multirow{4}{*}{$\begin{array}{l}\text { Cottonseed oil } \\
\text { cake }\end{array}$} & \multirow[t]{4}{*}{$\mathrm{MgO}$} & $\mathrm{O}, \mathrm{wt} \%$ & 9.56 & 4.90 & \multirow[t]{4}{*}[56]{} \\
\hline & & $\mathrm{O} / \mathrm{C}$ & 0.10 & 0.05 & \\
\hline & & $\mathrm{H} / \mathrm{C}$ & 1.83 & 1.87 & \\
\hline & & $\mathrm{HHV}, \mathrm{MJ} / \mathrm{kg}$ & 39.83 & 42.91 & \\
\hline
\end{tabular}

\section{Conclusion}

Pyrolysis becomes a prospective alternative to convert biomass into fuels and other chemicals, since it able to convert almost of the raw materials into usable product. However, bio-oils derived from biomass through the pyrolysis have low stability and also lower calorific value, particularly due to high oxygenated compounds contained in the oils. Catalytic upgrading becomes option to increase the quality of bio-oil regarding to the high oxygen content. Several studies have been carried out to develop the possibility to conduct upgrading 
process in single step through catalytic pyrolysis. Previous studies shown that the application of catalytic pyrolysis able to reduce the oxygen content of bio-oil, and also enhance the properties of bio-oils include the acidity, viscosity, and higher heating value as well. Searching of more effective catalysts, and also process modification of pyrolysis still becomes an attractive challenge, particularly to find out new technology that able to provide alternative energy sources in lower cost and highly sustainable. The mechanism and reaction pathways of biomass pyrolysis process are also interested to be studied in order to enhance the understanding of pyrolysis process.

\section{References}

[1] R. Hernandez, "Petroleum displacement potential of next generation biofuels approaching commercialization," Curr. Opin. Chem. Eng., vol. 1, no. 1, pp. 43-46, Oct. 2011.

[2] P. M. Mortensen, J.-D. Grunwaldt, P. a. Jensen, K. G. Knudsen, and a. D. Jensen, "A review of catalytic upgrading of bio-oil to engine fuels," Appl. Catal. A Gen., vol. 407, no. 1-2, pp. 1-19, Nov. 2011.

[3] O. D. Mante, F. a Agblevor, S. T. Oyama, and R. McClung, "The influence of recycling non-condensable gases in the fractional catalytic pyrolysis of biomass.," Bioresour. Technol., vol. 111, pp. 482-90, May 2012.

[4] G. Fogassy, N. Thegarid, Y. Schuurman, and C. Mirodatos, "From biomass to bio-gasoline by FCC coprocessing: effect of feed composition and catalyst structure on product quality," Energy Environ. Sci., vol. 4, no. 12, p. 5068, 2011.

[5] S. D. Stefanidis, K. G. Kalogiannis, E. F. Iliopoulou, A. A. Lappas, and P. A. Pilavachi, "In-situ upgrading of biomass pyrolysis vapors: catalyst screening on a fixed bed reactor.," Bioresour. Technol., vol. 102, no. 17 , pp. 8261-7, Sep. 2011.

[6] A. Aho, A. Tokarev, P. Backman, N. Kumar, K. Eränen, M. Hupa, B. Holmbom, T. Salmi, and D. Y. Murzin, "Catalytic Pyrolysis of Pine Biomass Over H-Beta Zeolite in a Dual-Fluidized Bed Reactor: Effect of Space Velocity on the Yield and Composition of Pyrolysis Products," Top. Catal., vol. 54, no. 13-15, pp. 941-948, Aug. 2011.

[7] C. Torri, M. Reinikainen, C. Lindfors, D. Fabbri, A. Oasmaa, and E. Kuoppala, "Investigation on catalytic pyrolysis of pine sawdust: Catalyst screening by Py-GC-MIP-AED,” J. Anal. Appl. Pyrolysis, vol. 88, no. 1, pp. 7-13, May 2010

[8] M. S. Abu Bakar and J. O. Titiloye, "Catalytic pyrolysis of rice husk for bio-oil production," J. Anal. Appl. Pyrolysis, vol. 103, pp. 362-368, 2013.

[9] J. Shao, R. Yan, H. Chen, H. Yang, and D. Ho, "Catalytic effect of metal oxides on pyrolysis of sewage sludge,” Fuel Process. Technol., vol. 91, no. 9, pp. 1113-1118, 2010.

[10] A. Aho, N. Kumar, K. Eränen, T. Salmi, M. Hupa, and D. Y. Murzin, "Catalytic pyrolysis of woody biomass in a fluidized bed reactor: Influence of the zeolite structure," Fuel, vol. 87, no. 12, pp. $2493-$ 2501, Sep. 2008.

[11] S. Thangalazhy-Gopakumar, S. Adhikari, R. B. Gupta, M. Tu, and S. Taylor, "Production of hydrocarbon fuels from biomass using catalytic pyrolysis under helium and hydrogen environments.," Bioresour. Technol., vol. 102, no. 12, pp. 6742-9, Jun. 2011.

[12] A. Güngör, S. Önenç, S. Uçar, and J. Yanik, “Comparison between the 'one-step' and 'two-step' catalytic pyrolysis of pine bark,” J. Anal. Appl. Pyrolysis, vol. 97, pp. 39-48, Sep. 2012.

[13] R. French and S. Czernik, "Catalytic pyrolysis of biomass for biofuels production," Fuel Process. Technol., vol. 91, no. 1, pp. 25-32, Jan. 2010.

[14] J. Li, X. Li, G. Zhou, W. Wang, C. Wang, S. Komarneni, and Y. Wang, “Applied Catalysis A : General Catalytic fast pyrolysis of biomass with mesoporous ZSM-5 zeolites prepared by desilication with $\mathrm{NaOH}$ solutions," "Applied Catal. A, Gen., vol. 470, pp. 115-122, 2014.

[15] M. Misson, R. Haron, M. F. A. Kamaroddin, and N. A. S. Amin, "Pretreatment of empty palm fruit bunch for production of chemicals via catalytic pyrolysis.," Bioresour. Technol., vol. 100, no. 11, pp. 2867-73, Jun. 2009.

[16] P. Pan, C. Hu, W. Yang, Y. Li, L. Dong, L. Zhu, D. Tong, R. Qing, and Y. Fan, "The direct pyrolysis and catalytic pyrolysis of Nannochloropsis sp. residue for renewable bio-oils.," Bioresour. Technol., vol. 101, 
no. 12, pp. 4593-9, Jun. 2010.

[17] B. B. Uzun and N. Sarioğlu, "Rapid and catalytic pyrolysis of corn stalks," Fuel Process. Technol., vol. 90, no. 5, pp. 705-716, May 2009.

[18] H. Zhang, R. Xiao, H. Huang, and G. Xiao, "Comparison of non-catalytic and catalytic fast pyrolysis of corncob in a fluidized bed reactor.," Bioresour. Technol., vol. 100, no. 3, pp. 1428-34, Feb. 2009.

[19] D. L. Compton, M. A. Jackson, D. J. Mihalcik, C. A. Mullen, and A. A. Boateng, "Catalytic pyrolysis of oak via pyroprobe and bench scale, packed bed pyrolysis reactors," J. Anal. Appl. Pyrolysis, vol. 90, no. 2, pp. 174-181, Mar. 2011.

[20] G. Chen, "Catalytic Application to Biomass Pyrolysis in a Fixed Bed Reactor," Energy Sources, vol. 25, no. 3, pp. 223-228, Mar. 2003.

[21] I. Demiral and S. Sensöz, "The effects of different catalysts on the pyrolysis of industrial wastes (olive and hazelnut bagasse).," Bioresour. Technol., vol. 99, no. 17, pp. 8002-7, Nov. 2008.

[22] S. Yorgun and Y. E. Simşek, "Catalytic pyrolysis of Miscanthus x giganteus over activated alumina.," Bioresour. Technol., vol. 99, no. 17, pp. 8095-100, Nov. 2008.

[23] H. J. Park, H. S. Heo, Y.-K. Park, J.-H. Yim, J.-K. Jeon, J. Park, C. Ryu, and S.-S. Kim, “Clean bio-oil production from fast pyrolysis of sewage sludge: effects of reaction conditions and metal oxide catalysts.," Bioresour. Technol., vol. 101, no. 1, pp. S83-5, Jan. 2010.

[24] X. Y. Lim and J. M. Andrésen, "Pyro-catalytic deoxgenated bio-oil from palm oil empty fruit bunch and fronds with boric oxide in a fixed-bed reactor," Fuel Process. Technol., vol. 92, no. 9, pp. 1796-1804, Sep. 2011.

[25] L. Zhou, H. Yang, H. Wu, M. Wang, and D. Cheng, "Catalytic pyrolysis of rice husk by mixing with zinc oxide : Characterization of bio-oil and its rheological behavior," Fuel Process. Technol., vol. 106, pp. 385-391, 2013.

[26] M. I. Nokkosmaki, E. T. Kuoppala, E. A. Leppamaki, and A. O. I. Krause, "Catalytic conversion of biomass pyrolysis vapours with zinc oxide,” J. Anal. Appl. Pyrolysis, vol. 55, pp. 119-131, 2000.

[27] I. V. Babich, M. van der Hulst, L. Lefferts, J. . Moulijn, P. O'Connor, and K. Seshan, "Catalytic pyrolysis of microalgae to high-quality liquid bio-fuels," Biomass and Bioenergy, vol. 35, no. 7, pp. 3199-3207, Jul. 2011.

[28] M. M. Barbooti, F. K. Matlub, and H. M. Hadi, "Catalytic pyrolysis of Phragmites (reed): Investigation of its potential as a biomass feedstock," J. Anal. Appl. Pyrolysis, vol. 98, pp. 1-6, Nov. 2012.

[29] P. Rutkowski, "Pyrolysis of cellulose, xylan and lignin with the $\mathrm{K} 2 \mathrm{CO} 3$ and $\mathrm{ZnCl} 2$ addition for bio-oil production," Fuel Process. Technol., vol. 92, no. 3, pp. 517-522, Mar. 2011.

[30] T. S. Nguyen, M. Zabeti, L. Lefferts, G. Brem, and K. Seshan, "Catalytic upgrading of biomass pyrolysis vapours using faujasite zeolite catalysts," Biomass and Bioenergy, vol. 48, pp. 100-110, 2013.

[31] A. V. Bridgwater, "Catalysis in thermal biomass conversion," Appl. Catal. A Gen., vol. 116, no. 1-2, pp. 5-47, Sep. 1994

[32] S. Thangalazhy-Gopakumar, S. Adhikari, S. A. Chattanathan, and R. B. Gupta, "Catalytic pyrolysis of green algae for hydrocarbon production using H+ZSM-5 catalyst.," Bioresour. Technol., vol. 118, pp. 150-7, Aug. 2012.

[33] L. Wang, H. Lei, S. Ren, Q. Bu, J. Liang, Y. Wei, Y. Liu, G.-S. J. Lee, S. Chen, J. Tang, Q. Zhang, and R. Ruan, "Aromatics and phenols from catalytic pyrolysis of Douglas fir pellets in microwave with ZSM5 as a catalyst," J. Anal. Appl. Pyrolysis, vol. 98, pp. 194-200, Nov. 2012.

[34] D. A. Bulushev and J. R. H. Ross, "Catalysis for conversion of biomass to fuels via pyrolysis and gasification: A review," Catal. Today, vol. 171, no. 1, pp. 1-13, Aug. 2011.

[35] A. López, I. De Marco, B. M. Caballero, A. Adrados, and M. F. Laresgoiti, "Deactivation and regeneration of ZSM-5 zeolite in catalytic pyrolysis of plastic wastes," Waste Manag., vol. 31, pp. 1852$1858,2011$.

[36] E. F. Iliopoulou, S. D. Stefanidis, K. G. Kalogiannis, A. Delimitis, A. A. Lappas, and K. S. Triantafyllidis, "Catalytic upgrading of biomass pyrolysis vapors using transition metal-modified ZSM-5 zeolite," Appl. 
Catal. B Environ., vol. 127, pp. 281-290, Oct. 2012.

[37] H. Zhang, Y.-T. Cheng, T. P. Vispute, R. Xiao, and G. W. Huber, "Catalytic conversion of biomassderived feedstocks into olefins and aromatics with ZSM-5: the hydrogen to carbon effective ratio," Energy Environ. Sci., vol. 4, no. 6, p. 2297, 2011.

[38] P. A. Home and P. T. Williams, "Premium quality fuels and chemicals from the fluidised bed pyrolyisi of biomass with zeolite catalyst upgrading," Renew. Energy, vol. 5, pp. 810-812, 1994.

[39] P. T. Williams and P. a. Horne, "The influence of catalyst type on the composition of upgraded biomass pyrolysis oils,” J. Anal. Appl. Pyrolysis, vol. 31, pp. 39-61, Feb. 1995.

[40] S. Wang, Y. Zhou, T. Liang, and X. Guo, "Catalytic pyrolysis of mannose as a model compound of hemicellulose over zeolites,” Biomass and Bioenergy, vol. 57, pp. 106-112, 2013.

[41] D. J. Mihalcik, C. a. Mullen, and A. a. Boateng, "Screening acidic zeolites for catalytic fast pyrolysis of biomass and its components," J. Anal. Appl. Pyrolysis, vol. 92, no. 1, pp. 224-232, Sep. 2011.

[42] A. K. Dalai, E. Sasaoka, H. Hikita, and D. Ferdous, "Catalytic Gasification of Sawdust Derived from Various Biomass," Energy \& Fuels, vol. 17, no. 6, pp. 1456-1463, Nov. 2003.

[43] M. Mahishi and D. Goswami, "An experimental study of hydrogen production by gasification of biomass in the presence of a CO2CO2 sorbent," Int. J. Hydrogen Energy, vol. 32, no. 14, pp. 2803-2808, Sep. 2007.

[44] H. Guoxin and H. Hao, "Hydrogen rich fuel gas production by gasification of wet biomass using a CO2 sorbent," Biomass and Bioenergy, vol. 33, no. 5, pp. 899-906, May 2009.

[45] Y. H. Taufiq-Yap, S. Sivasangar, and a. Salmiaton, "Enhancement of hydrogen production by secondary metal oxide dopants on $\mathrm{NiO} / \mathrm{CaO}$ material for catalytic gasification of empty palm fruit bunches," Energy, vol. 47, no. 1, pp. 158-165, Nov. 2012.

[46] J. Udomsirichakorn and P. A. Salam, "Review of hydrogen-enriched gas production from steam gasification of biomass: The prospect of CaO-based chemical looping gasification," Renew. Sustain. Energy Rev., vol. 30, pp. 565-579, Feb. 2014.

[47] Y. Lin, C. Zhang, M. Zhang, and J. Zhang, "Deoxygenation of Bio-oil during Pyrolysis of Biomass in the Presence of $\mathrm{CaO}$ in a Fluidized-Bed Reactor,” Energy \& Fuels, vol. 24, no. 10, pp. 5686-5695, Oct. 2010.

[48] W. Kuan, Y. Huang, C. Chang, and S. Lo, "Catalytic pyrolysis of sugarcane bagasse by using microwave heating," Bioresour. Technol., vol. 146, pp. 324-329, 2013.

[49] K. Smets, A. Roukaerts, J. Czech, G. Reggers, S. Schreurs, R. Carleer, and J. Yperman, "Slow catalytic pyrolysis of rapeseed cake: Product yield and characterization of the pyrolysis liquid," Biomass and Bioenergy, vol. 57, pp. 180-190, 2013.

[50] A. Aho, N. Kumar, K. Eränen, T. Salmi, M. Hupa, and D. Y. Murzin, "Catalytic Pyrolysis of Biomass in a Fluidized Bed Reactor,” Process Saf. Environ. Prot., vol. 85, no. 5, pp. 473-480, Jan. 2007.

[51] S. A. Channiwala and P. P. Parikh, "A unified correlation for estimating HHV of solid, liquid and gaseous fuels," Fuel, vol. 81, pp. 1051-1063, 2002.

[52] A. Zheng, Z. Zhao, S. Chang, Z. Huang, H. Wu, X. Wang, F. He, and H. Li, "Journal of Molecular Catalysis A : Chemical Effect of crystal size of ZSM-5 on the aromatic yield and selectivity from catalytic fast pyrolysis of biomass," "Journal Mol. Catal. A, Chem., vol. 383-384, pp. 23-30, 2014.

[53] Y. Fan, Y. Cai, X. Li, N. Yu, and H. Yin, "Catalytic upgrading of pyrolytic vapors from the vacuum pyrolysis of rape straw over nanocrystalline HZSM-5 zeolite in a two-stage fixed-bed reactor," J. Anal. Appl. Pyrolysis, May 2014.

[54] N. Ozbay, A. E. Pütün, B. B. Uzun, and E. Pütün, "Biocrude from biomass: pyrolysis of cottonseed cake," Renew. Energy, vol. 24, pp. 615-625, 2001.

[55] E. Pütün, B. B. Uzun, and A. E. Pütün, "Production of bio-fuels from cottonseed cake by catalytic pyrolysis under steam atmosphere," Biomass and Bioenergy, vol. 30, no. 6, pp. 592-598, Jun. 2006.

[56] E. Pütün, "Catalytic pyrolysis of biomass: Effects of pyrolysis temperature, sweeping gas flow rate and MgO catalyst," Energy, vol. 35, no. 7, pp. 2761-2766, Jul. 2010. 